
col. 1.

${ }^{30}$ Ward's Own (Bloomfield, Iowa), July 9, 1857-April 18, 1858, p. 2,

${ }^{31}$ Macy, op. cit., p. 90.

${ }^{32}$ The State Press, July 6, 1864, p. 2, col. 1.

${ }^{33}$ Des Moines News (Keosauqua, Iowa), July 1, 1859, p. 2, col. 1. col. 1.

${ }^{34}$ The Weekly Courier (Muscatine, Iowa), April 15, 1864, p. 334,

${ }^{35}$ The State Press, February 24, 1864, p. 4, col. 2.

\title{
The Quest for Community in Rural Iowa: NEIGHBORHOOD LIFE IN EARLY MIDDLEBURG HISTORY
}

\author{
by \\ Gary Koerselman
}

Dr. Koerselman is a native of Sioux City, Iowa. He received his Ph.D. from Northern Illinois University in June of 1971 and specializes in twentieth-century American studies.

\section{Introduction}

Last year Dr. Koerselman published an article in the ANNALS entitled "The Church and Community Life in Early Middleburg History." Middleburg is a small hamlet located in the middle of Sioux County in Northwest Iowa. In last year's article, Dr. Koerselman contended that Middleburg's development was unique because the church filled the social vacuum created by the absence of such institutions as banks, elevators, and railroads. Also, Middleburg was never formally incorporated.

In the following article Dr. Koerselman analyzes the social impact of the "neighborhood" on agrarian life in Middleburg around the turn of the century.

Before historians can fully appreciate and understand the framework of agrarian society in America, they must consciously attempt to describe and define the functions of such institutions as the "neighborhood." Such an investigation is wrought with problems of definition and measurement, of course. Activities predicated upon the impulse of neighbor- 
liness were performed informally. As an unofficial institution without formal recognition, the neighborhood had no binding force over the lives of individuals. Usually the boundaries of any neighborhood were only awkwardly defined. Neighborhoods were not incorporated like cities and towns, neither did they elect officers nor solicit memberships. Yet, even though it is difficult to formulate a precise definition of the term, the neighborhood represented an undeniable social force which greatly influenced the lives of millions of rural Americans. Middleburg was no exception. ${ }^{1}$

In Middleburg the neighborhood ranked in importance closely behind such central institutions as family and church. The Bible-believing Dutch Reformers who established their farms around Bell's Lake in the 1870's developed a special allegiance to the principle of functioning as a "good neighbor." This allegiance was based partly upon their belief in the scriptural teachings of Jesus Christ and partly upon the conditions and circumstances of early life on the prairie. Scripturally, Middleburgers accepted without reservation Christ's teachings "to love thy neighbor as thyself" and to act "as thy brother's keeper." According to the position of the church an individual's relationships with his neighbors were essentially "outward" signs of his "inward" commitment to his professed faith in Christ. This position provided the social-intellectual rationale for the individual to discover his own social identity and to develop his feelings for community within the context of neighborhood. ${ }^{2}$

Along with the social-intellectual setting, the conditions and challenges of frontier life on the prairies established the physical need for neighborhood. From the beginning many important farm tasks were too complicated and cumbersome for one farmer to handle adequately. Hence, the necessity for cooperation in building the first houses, barns, granaries, and fences. Early settlers were obliged to take turns herding the livestock into grazing areas while others tilled the fields. They often traveled together by buckboard or wagon 25 miles south to Le Mars for provisions and supplies. They formed work parties to fetch firewood from along the banks of the Big Sioux River some 25 miles to the west. This was often an 
exasperating and dangerous endeavor which required farmers to travel armed with shotguns, rifles, and reliable watch dogs. They feared Indian intrigue and the possibility of marauding bandits running off with their horses. The guns also gave them a show of force which was sometimes necessary in negotiating with the woodland owners who were not above practicing extortion. Once the railroads had been extended beyond Le Mars to Sioux Center and Orange City, farmers also helped each other drive finished hogs and cattle to the nearest terminal for marketing in the Sioux City Stockyards. ${ }^{3}$

After 1885, when the land had become fully occupied and the general store firmly established in Middleburg, the earlier conditions underpinning the need for neighborhood cooperation were replaced by more durable and dynamic ones, both economic and social. Economic self-interest became the basis for neighborhood. Most farm operations continued to require more men, horses, and equipment than any single farmer could supply. The "haying" operation was the best example of this. ${ }^{4}$

The early-summer haying operation required a fundamental neighborhood effort. Hay was a relatively inexpensive roughage which was fed to the livestock in place of pasture grass during the winter months. It was derived from cutting slough grass, clover, or later, alfalfa. It had to be carefully stored in barns for protection from the harsh weather. Without this commodity farms around Middleburg could not have existed as they did.

The haying operation was a delicate one. Too much rain on a freshly cut hay crop would greatly decrease its quality. The objective, then, was to cut the hay, give it a few days to dry in the gusty early-summer winds, and "put up" the "cured" hay into barns before the rains came. The whole operation called for monumental guesswork as far as the weather conditions were concerned. About the only way to beat the weather was to move with all deliberate speed.

To accomplish this feat additional men and equipment were needed. Three or four hay racks and teams of horses were required to "haul in" the hay from the field. In years of heavy rainfall, when the narrow steel wheels of the run- 
ning-gears supporting the hayracks sunk deeply into the soft and mucky slough mud, even more horses were needed. Additional teams were also needed in the barnyard to hoist the hay, loaded onto sling ropes, into the hay barns. Six or eight men usually attended the operation, which involved stacking the hay first on the racks, then hauling it into the yard, and finally, the grueling task of leveling it in the haymow of the barns. ${ }^{5}$

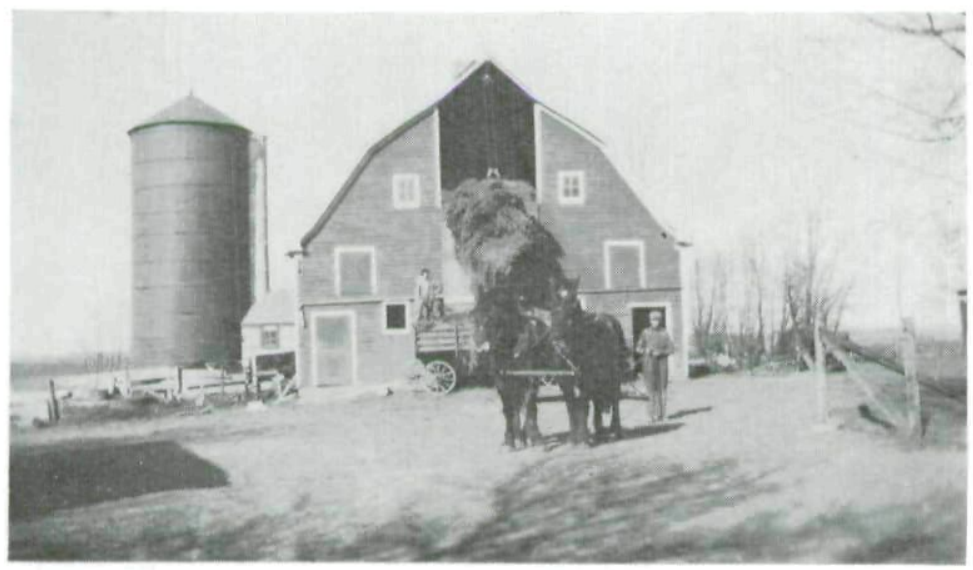

Courtesy of Author

This picture depicts Middleburg's haying operation. The farmers are hoisting hay into the barn with sling ropes. Photo was taken in 1921 .

In time a machine known as the "hay loader" was introduced into the haying operation by such machinery companies as Case, International Harvester, and John Deere. As was typical with most machines, the hay loader increased the efficiency of the haying operation and reduced the amount of manual labor, but it was expensive. Consequently, farmers were prone to own a hay loader jointly. As a result, three or four farmers would pool their resources in order to attain greater effiiciency and to protect the quality of the hay crop. Indeed, haying became a neighborhood affair. ${ }^{6}$

The hot and humid weather conditions which accompanied the growing season made haying the most difficult and exhausting task of the entire farming operation. Temper- 


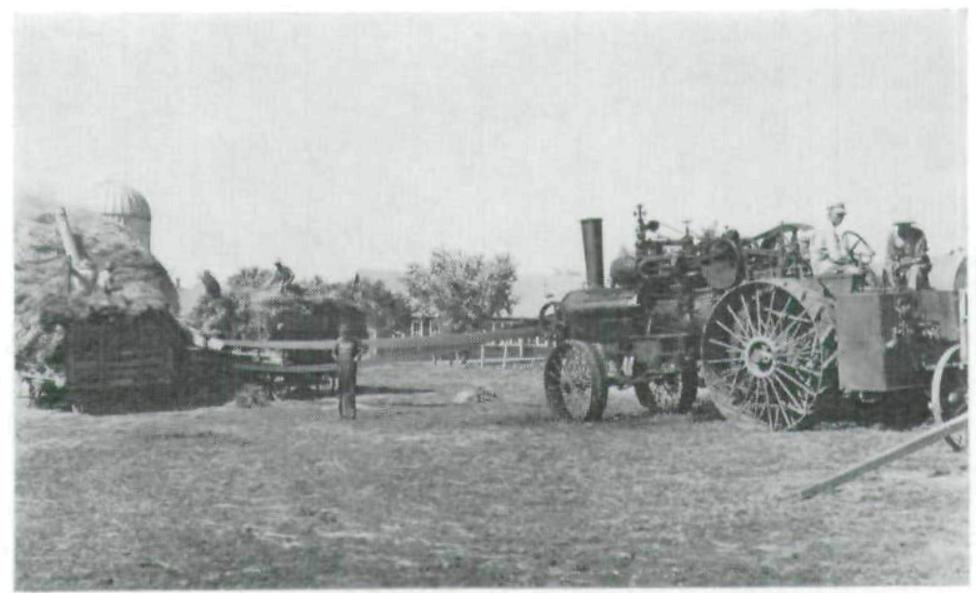

Courtesy of Author

Photo of Middleburg's threshing operation. Note immense tractor and straw stack. Bundle wagon (background) is being unloaded into threshing machine.

atures in the hay barns often ranged over 100 degrees. Indeed, the men who toiled and sweated together in their race against the weather (and the women who supported their efforts with food and drink) could not help but develop very close feelings of kinship. They became acquainted with each other's habits and interests. They confided in one another. They counseled each other on economic, social, and religious matters. The haying operation, then, served as a basis for a kind of inner neighborhood. Usually, the most intimate and enduring personal relationships evolved within this small circle of human beings. ${ }^{7}$

However, the bounds of neighborhood in Middleburg went beyond the small circle of farmers who performed their haying operations together. The mid-summer oat harvest, which came to require very sophisticated cooperation among neighbors, formed an even broader foundation for neighborhood. Whereas oats are raised sparingly today and generally only for silage purposes, at the turn of the century almost half of the 80 to 200 acre farms around Middleburg was reserved for oats. On the one hand, oats served as primary feed for the horses; on the other hand, oats could quite profitably be 
alternated with the main grain crop, corn, in order to replenish the productivity of the soil. ${ }^{8}$

The oat crop ripened early in July. Each farmer cut and bundled his crop and stacked it in small shocks to dry. In the earliest times the farmers would simply pile the unthreshed bundles on larger stacks to be threshed much later in the season. This method exposed the oat crop to adverse weather conditions, however, and caused unnecessary waste. To overcome this waste, farmers resolved to organize into "threshing rings" of eight to twelve farmers. One or two of these farmers agreed to purchase and operate a threshing machine and custom-thresh everyone else's crop.

The man who owned and tended the threshing machine soon became known as the "thresherman." Besides mastering the gigantic machine which growled and ground its way through the countryside, the thresherman became responsible for organizing and coordinating the entire threshing operation. Indeed, he became recognized as the chief officer-the leader. He was usually respected, often revered, for his mechanical and organizational abilities. His personality traits and habits often served as the topic for neighborhood conversation and gossip. Rather than worship football and baseball heroes, the young men of Middleburg dreamed of one day emulating the role of the thresherman in the community. In instances where the thresherman enjoyed such rapport, the entire neighborhood became known by his name-such as the Bomgaars or the Cander Maaten neighborhood. ${ }^{9}$

As they worked and toiled together under a variety of conditions from early July to middle or late August, the cooperating farmers of the threshing ring shared many pleasant as well as unpleasant experiences and, thus, became very well acquainted with each other. They became aware of eachother's personal strengths and weaknesses. Through a variety of interrelationships, each individual received opportunities to embrace certain roles within the group and to project a particular and distinctive image of himself. One man became known for his tardiness-always a half hour late in the morning and he could never keep his pace with his threshing partner; another became known for his exceptional ability to stack 
straw; another for his quips and anecdotes; another for his practical jokes; and, still another for the exotic patches on his coveralls. Farmers became conscious of their status within the group. An individual's rapport depended on such things as his honesty, his strength, the disposition and training of his team, his ability to stack straw and load bundle wagons, and the quality and the quantity of his oats crop. An ill-mannered and poorly trained team, a load of bundles upset into a ditch or creek, an uneven crop in a poorly tilled field, or an abundance of sunflowers and thistles all subtracted from one's reputation.

In spite of the difficult work, farmers found many opportunities to converse with one another. Sometimes it was in the shade of bundle wagons while waiting for their turn to unload into the threshing machine. Sometimes it was in barns while operations were being interrupted by a rain storm. At other times it was around a "broken-down" or "clogged" threshing machine. The best place for conversation, however, was around the dinner table at noon. The entire threshing operation halted promptly at noon. After each thresher had taken ample time to wash away the sticky threshing dust from his brow, the

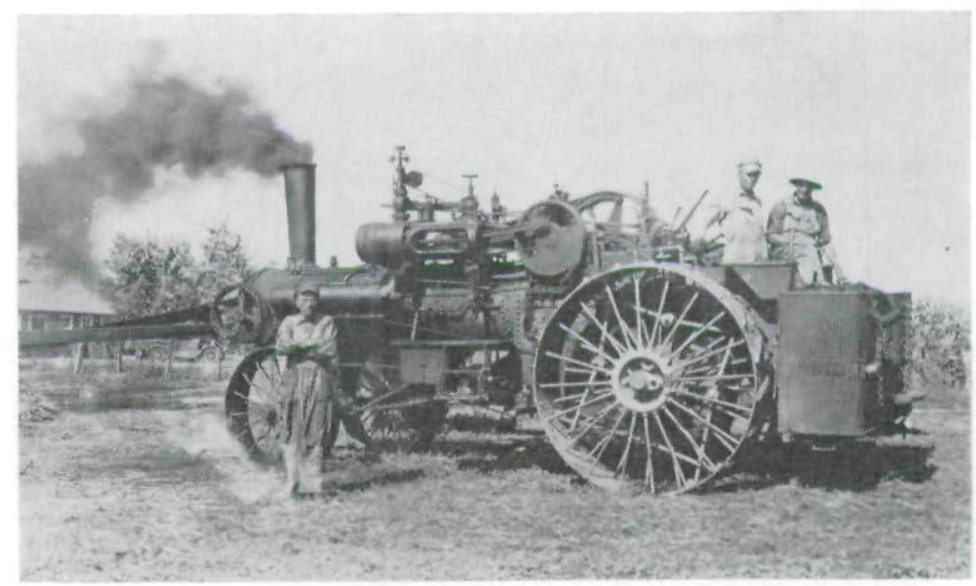

Courtesy of Author

Pictured here is Gerrit Ruisch (standing by front wheel of tractor) who was one of the most famous thresher-men in the Middleburg area. From 1888 to 1947 he threshed more than three million bushels of oats. 
voracious farmers eagerly gathered around food-laden tables in the farm house to enjoy jovial talk and dinner especially prepared by the wives. Such a dinner featured such essentials as milk, meat, vegetables, potatoes, and always "ma's" favorite homemade pie. No one ever expected to leave the table unsatisfied. The head of the household was expected to begin the meal with "a word of prayer" and follow it with "a reading of the scriptures."

The weather was generally the major topic of discussion. Everyone dreaded the thought of a rainstorm which might forestall the threshing operations and reduce the quality of the unthreshed grain still in the field. Everyone knew the foreboding natural signs which portended rain-the "sun dogs" in the evening western sky, a strong breeze blowing in from the east, higher than usual humidity, and nervousness among the horses. Farmers continually looked for and analyzed the signs. Some went as far as to predict a storm whenever the thresherman was in an impatient or grisly mood. The concern over the next day's weather conditions led to much speculation and many stories and yarns about how weather conditions had interrupted threshing in the past. The views of the older men were often solicited, but they wisely resisted these queries. Their long experience with the unpredictable weather conditions of northwestern Iowa had taught them not to make any definite forecasts. This very unpredictability, however, kept the topic constantly alive.

The many personal interrelationships which attended the threshing operations, then, formed the basis for the kind of community spirit which helped people to develop an allegiance to their neighborhood. No other single farm operationbe it house-warming, haying, corn-picking, fence-mending, butchering, sorting cattle and hogs for market, or breaking young horses-united the neighborhood like threshing. ${ }^{10}$

Certain principles or unwritten rules began to emerge as acceptable standards of conduct for neighbors. Individuals began to consider their role as neighbor almost as important as their roles within the family and the church. The obligation to be a "good neighbor" became so engrained in the Middleburg community that even some of the wealthier farmers, who 
could better have afforded to singularize his farming operations, bent to social pressure and went on working and cooperating with their neighbors as a matter of principle.

According to the emerging standard of conduct, a good neighbor displayed an astute sense of fairness in all of his dealings and associations. He never returned a borrowed piece of equipment in disrepair. He always returned a fair portion of labor. If this was physically impossible, recompense was made in the form of money or by performing other small farm services such as dehorning cattle, cleaning oats, building corn cribs, or shoeing horses.

A good neighbor, like a good professional, never spoke evil of his fellow unless that man's irresponsibility and dishonesty had been demonstrated beyond doubt. Even then, a good neighbor was expected to lend a helping hand to his unfortunate brother. He was to act as mediator between a recalcitrant neighbor and the church, the law, the banker, or, even to arbitrate domestic disputes between husband and wife or father and son.

A good neighbor was always friendly and willing to talk. He always waved when riding by on the road. This friendliness sometimes bordered on the flippant side. He readily stopped his cultivating or plowing in the field for a short "across-the-fence" chat with his counterpart about such things as the progress of the corn crop, the virile nature of noxious weeds, the conditions of the soil, or whatever happened to be relevent to the season.

A good neighbor could be counted upon in times of emergency and strife. In an age before pain-reducing drugs, when doctors and hospital facilities were not readily available, childbirth was a dreadful and harrowing experience. Whenever a pending birth was expected, the neighbor lady acted as the midwife, soothing the fears of the expectant mother, while her husband hurried off to near-by Pattersonville (Hull) to summon the doctor. In a winter snow storm this trip could become quite an ordeal. Men would put newspapers inside their coats to keep warm and dry. Once in a while a man would lose his way and have to depend upon the instinct of his horses to find the way home. 
A good neighbor volunteered his unreserved assistance in times of sickness, injury, or death. When sickness or injury struck, neighbors harvested entire crops and performed the chores for months at a time. In time of death neighbors handled the funeral arangements and performed the chores during the time of mourning. It became customary to hold a short service for neighbors and relatives in the home before the regular funeral service in the church. Except for weddings, the front door leading into the living room was used only during funerals. Otherwise guests expected to be welcomed at the back door leading into the kitchen.

Some rare individuals took advantage of the spirit of neighborliness. One man, for example, had just completed the tedious task of digging a well single-handedly, only to discover one morning that it had caved in. Not relishing the thought of removing so much earth from his new well, he resorted to some very clever antics. He hung his hat and coat on his shovel close to the opening of the well in a fashion which gave the distinct impression that he had become a victim of the cave-in. Then he went back to his house and watched and waited. Soon one of his neighbors came riding along and upon noticing the apparent disaster quickly summoned assistance from the neighborhood. Within an hour the frantic neighbors had completely removed all the earth from the well. Just then the grateful owner happened back on the scene and graciously thanked everyone for their kindness and consideration.

A good neighbor conformed to the ethos of the community. Nonconformity or slothfulness might tarnish the image and reputation of the entire neighborhood. Everyone was, therefore, expected to adhere to strict moral codes. Alcohol was used only on rare occasions and then in strict moderation. Regular church attendance was expected. Dancing, Cardplaying, and profanity were frowned upon. Fences were to be in adequate repair, buildings maintained and freshly painted, animals well-attended, and the rows of corn planted as evenly as possible. In keeping with Dutch tradition, a good neighbor was expected to be a neat and thrifty farm operator. It took "Yappy" Cermaat, a conscientious farmer, some time to live down the scandal caused by the dead cat which the 
cream hauler discovered in a can of cream "Yappy" had placed at the end of his lane for marketing.

Neighbors were not above competing with each other in various ways. In the suburbs this competition would have been dubbed "keeping up with the Joneses." An individual farmer's prestige was connected to many things. Such things as the best-groomed horses, the finest carriages, the tallest windmills, the biggest barns, the largest home-raised watermelons, the largest number of fertile acres, the greatest number of milch cows, the daintiest ladies, and the tastiest home-made wine could all bring about added degrees of recognition and prestige. Farmers competed to be the first into the field in the spring and the first finished with corn-picking in the fall. This competition was usually good-natured, seldom pernicious, and added an important dimension to life in Middleburg. It added a zestful spirit to aspects of life which ordinarily would have spelled boredom and islolation.

The individual who did not measure up to the expectations of a neighbor soon found himself ostracized in the community; sometimes he became regarded much as a hermit, and portrayed by parents to their children as the best example of a "bad Christian." Whenever a neighbor treated another unjustly or whenever neighbors became involved in a feud, they voluntarily absented themselves from the sacrament of communion until the problem had been resolved. A feud involving a farmer's chickens which had broken through a fence into his neighbor's garden and scratched out many tender tomato plants continued for many years. This irreconcilable feud revolved around the unanswerable question of what came first, the unmended fence or the marauding chickens.

An example of a more serious feud, involving many more people, resulted from the introduction of the motor truck in 1904 to transport farmers' cream from the farmyard to the creamery in town. Previously, horse-drawn wagons had been employed for this task. Many farmers heartily endorsed the advent of the motor truck in the name of progress and increased efficiency. Some farmers were extremely apprehensive, however, arguing that the motor truck replaced the need for 
horses and hence reduced the demand for oats. They were also disturbed because motor trucks consumed oil products produced by such monopolists as John D. Rockefeller, who were considered exploiters of the farmers. Finally, they detested the uncomely and annoying noise emitting from the slike engine of the new-fangled trucks-a noise which greatly disrupted the peaceful quietude of the countryside. In spite of such temporary differences over the introduction of the motor truck, however, the neighborhood was able to maintain its cohesion before World War I. ${ }^{11}$

The essential basis for neighborhood in Middleburg, then, was mutual economic self-interest. Out of economic concert developed several interpersonal relationships and conforming codes of conduct. From this grew a variety of social activities. Social activity constituted the final ingredient which bound the neighborhood together into a coherent community.

The annual thresher's picnic, which followed closely on the heels of the oat harvest, evolved into the most significant neighborhood social event. Celebrated in one of the more elaborate orchards or groves, the thresher's picnic featured homemade apple pie, softball and horseshoes, and tales about the old days. Every threshing ring had a softball team and often the home team squared off against an adjacent neighborhood team on the afternoon of the picnic.

Customarily, this was the day for the farmers to pay the thresherman for his services. Also, in the course of the afternoon, the thresherman led in the planning of next year's threshing schedule. Farmers were expected to alternate turns. If a farmer was at the beginning of the list one year, he could expect to be placed toward the end the following year. When this happened he could plant a brand of oat which ripened later in the season so that he would not have to cut it as early. The threshermen's picnic, then, provided much good wholesome fellowship, an occasion for organization and planning, and, of course, an opportunity for the younger people to become better acquainted.

Not surprisingly, many intra-neighborhood marriages occurred. The marriage ceremony and feast, which took place in the elaborately decorated living room of the bride's parents, 
included neighbors among the most important guests. The unmarried sons and daughters of neighbors tended the horses of the guests and served the food and drink.

Since few newly-married couples embarked upon a honeymoon, it became customary to shivaree the newly-weds on their first night together. This took place after all other wedding festivities had ended and the young couple was tucked away safely in their new quarters. The shivareers, consisting mostly of young people from the neighborhood, then stole into the front yard and at an appropriate moment began to create an uproarious disturbance by beating on empty kettles, shaking strings of empty tin cans, and serenading loudly and boisterously. This commotion persisted until the groom, usually clad in gaudy pajamas, made a humble appearance and bargained the intruders away with treats ranging from chocolate candy to wine. The marriage ceremony, then, amounted to a gala event which involved and unified the entire neighborhood.

Another important neighborhood event was the farewell reception held in honor of families who were moving away. Such receptions became particularly significant when an older couple, who had been a part of the neighborhood for years, retired in order to "move to town." On such occasions expensive gifts and heart-felt testimonials were in order. The older couple's place in the neighborhood was usually taken over by their son and his family. Thus, the same family occupied a farm for generations.

The neighborhood provided many other opportunities for socializing. Whenever a neighbor stopped by for any reason, he was automatically invited to stay for "a cup of coffee" and "a piece of applesauce cake." Neighbors often gathered for "coffee" on Sunday afternoon after church services. Neighborhood tobogganing parties or skating parties on Bell's Lake became the order of the day. Men enjoyed hunting and fishing together. During the winter men gathered often for checkers, or, sometimes, just to "whittle" and talk things over. Women often assisted each other with "housecleaning," a major cleaning operation performed every spring and fall whether necessary or not. 
Thus, between 1885 and 1920, the informal and makeshift instutition known as the neighborhood gradually became an essential part of Middleburg life. The serene institution could not sustain the pressures of twentieth-century life, however. The impact of World War I, the advent of the automobile and tractor, the introduction of the radio and the telephone, and, later, the land consolidation of the thirties and after disrupted traditional neighborhood ties and loyalties. The nationalistic fervor engendered by the war abruptly jolted the people's attention away for purely provincial concerns. The automobile prompted families to drive elsewhere for social and recreational activity. The tractor and modern machinery, like combines and hay balers, largely negated the need for neighborly cooperation. The radio and telephone made the whole world into a neighborhood.

Today, the word "neighborhood" no longer commands the respectful allegiance that it once did. The farmers of Middleburg, as everywhere else, boast of their autonomy and self-sufficiency. Lost, however, is the remarkable spirit of neighborliness which once laced and bound the community together.

\section{NOTES}

${ }^{1}$ The bulk of material for this article was gathered through personal correspondence and interviews with the following people: Henry De Groot, Mrs. Elizabeth De Leeuw, Jake Dykstra, William Kalsbeek, Ben Vander Griend, Frank Vander Wilt, John Wiersma, and Herman Vander Maten, all of Orange City, Iowa; Gerrit Franken, Gerrit Koerselman, and Rev. John Roggen, of Sioux Center, Iowa; Jake De Zeeuw and Henry Wissink of Boyden, Iowa; and Henry Koerselman of Hull, Iowa.

${ }^{2}$ For valuable background material on the region, see Jacob Van Der Zee, The Hollanders in Iowa (Iowa City, Iowa, 1912).

${ }^{3}$ Interview with Jake De Zeeuw, Boyden, Iowa, August 27, 1964. Also see Charles L. Dyke, The Story of Sioux County (Orange City, Iowa, 1942), p. 75.

${ }^{4}$ Interview with Gardy Wiersma, Orange City, Iowa, July 28, 1964. Also see Fred A. Shannon, "The Status of the Midwestern Farmer in 1900," Mississippi Valley Historical Review, XXXVII (December, 1950), pp. 491-510.

${ }^{5} \mathrm{~A}$ single two-year-old horse cost around $\$ 150$, for example, a substantial sum for that time. See Rock Valley Bee (February 22, 1907). Also see L. H. Bailey, Cyclopedia of American Agriculture, Vol. I, Farms (New York, 1912), p. 168.

${ }^{6}$ Iowa State College, A Century of Farming in Iowa, 1846-1946 (Ames, Iowa, 1946), pp. 225-248. 
${ }^{7}$ Atlas of Sioux County, Iowa, Section II (Chicago, 1908), p. 6. 187.

${ }^{8}$ William H. Clark, Farms and Farmers (Boston, 1945), pp. 156-

${ }^{9}$ Some of the flavor of the threshing season was revealed in C. L. Miller, "Call of the Harvest," Colliers, L (October 5, 1912), p. 42.

${ }^{10}$ An analysis of rural social life around the turn of the century suggests that President Theodore Roosevelt's Report of the Country Life Commission failed in many ways to understand or discover the bonds of community which actually existed in rural America. See Report of the Country Life Commission (60 Congress, II Session, Senate Documents 705, Serial 5408, Washington, 1909).

${ }^{11}$ Alton Democrat (October 1, 1904).

\section{Antique Car Donated To Museum}

On Tuesday, May 16, 1972, the Department of History and Archives in Des Moines was given a nostalgic momento of Iowa's early motoring era. The Maytag Company of Newton, Iowa donated to the Museum a 1910 Maytag Pleasure car. The automobile is in excellent condition, has all of its working parts, and is now on display in the basement area of the museum.

A brief perusal of the history of the Maytag shows that it was manufactured in the years $1909-1910$ by the MaytagMason Motor Car Company-an offshoot of the Mason Motor Car Company of Waterloo. In 1909 F. L. Maytag decided to expand his interests and invested $\$ 300,000$ in Edward B. Mason's automobile Company. ${ }^{1}$ Mason needed the capital, and Maytag was interested in becoming a part of the exciting and expanding automobile manufacturing industry. Maytag gradually assumed control of the Company, and its name was then changed to Maytag-Mason Company.

The Maytag Pleasure car is an example of one of the first cars manufactured by the Company. It contains a twocylinder engine designed by Fred and August Duesenberg, and was acclaimed for its climbing power. The car was ad-

${ }^{1}$ George S. Mills, Rogues and Heroes from Iowa's Amazing Past (Ames: The Iowa State University Press, 1972), p. 18. 
Copyright of Annals of Iowa is the property of State of Iowa, by \& through the State Historical Society of Iowa and its content may not be copied or emailed to multiple sites or posted to a listserv without the copyright holder's express written permission. However, users may print, download, or email articles for individual use. 